\title{
Detection OF ACETYLCHOLINESTERASE ACtiVity AND GAMMA-AMINOBUTYRIC ACID BINDING SITES IN DICROCOELIUM DENDRITICUM
}

\author{
GIMÉNEZ-PARDO C*., ROS-MORENO R.M.*, ARMAS-SERRA C. DE* \& RODRIGUEZ-CAABEIRO F.*
}

\section{Summary :}

In the present study we report the presence of acetylcholinesterase activity and gamma-aminobutyric acid binding sites in crude extracts of Dicrocoelium dendriticum. This indirectly demonstrates the presence of acetylcholine and GABA. The presence of these neurotransmitters could indicate the existence of two systems implicated in the neurotransmission of the Digenea.

KEY WORDS : Dicrocoelium dendriticum, neurotransmitters.
Résumé : DÉTECTION D'UNE ACTIVITÉ ANTICHOLINESTÉRASIQUE ET DE SITES DE FIXATION DE L'ACIDE GAMMA-AMINOBUTYRIQUE CHEZ DICROCOELIUM DENTRITICUM

Cette étude rapporte la présence d'une activité anticholynestérasique et de sites de fixation de l'acide gammaaminobutyrique (GABA) dans des extraits de Dicrocoelium dendriticum. Ceci prouve indirectement la présence d'acétylcholine et de GABA, et permet de poser l'hypothèse de l'existence de deux systèmes impliqués dans la neurotransmission des Digènes.

MOTS CLÉS : Dicrocoelium dentriticum, neurotransmetteurs.

\section{INTRODUCTION}

$\Lambda$ in cetylcholine is known to influence mobility in platyhelminths and to activate the metabolism in trematodes and cestodes. Conversely, as recent work has shown, GABA exerts an inhibitory effect in platyhelminths. Most of our present knowledge comes from studies on Schistosoma spp. and Fasciola bepatica (Geary et al., 1992; Erikson \& Panula, 1994; Walker Brooks \& Holden-Dye, 1996), but little is known about the molecules implicated in neurotransmission in Dicrocoelium dendriticum, one of the most common pathogens of domestic animals. Since certain drugs are believed to affect receptors, these molecules might be proposed as attractive targets for chemotherapy in parasitic diseases. The present study has $i$ ) characterized acetylcholinesterase activity in crude extracts of Dicrocoelium dendriticum, indicating indirectly the presence of acetylcholine (Walker \& Holden-Dye, 1991) and ii) made a preliminary study of GABA receptors in whole extracts from this parasite using binding assays. The object was to collect new data on the molecules implicated in neurotransmission in flatworms and in platyhelminths generally.

\footnotetext{
* Parasitology Laboratory, Faculty of Pharmacy, University of Alcalá, Crtra. Madrid-Barcelona Km. 33.600, 28871 Alcalá de Henares, (Madrid) Spain.

Correspondence: Consuelo Giménez Pardo.

Tel: +34 18854636 - Fax: +3418854663.

E-mail: consuelo.gimenez@uah.es
}

\section{MATERIALS AND METHODS}

\section{COLLECTION AND PREPARATION OF CYTOSOLIC FRACTION}

dult $D$. dendriticum were removed from the
gallbladder and bile ducts of sheep at the muni-
cipal slaughterhouse in Alcalá de Henares (Spain). The worms were washed several times with $10 \mathrm{mM}$ PBS pH 7.2 with added penicillin $(1 \mathrm{mg} / \mathrm{ml})$ and streptomycin sulphate $(2 \mathrm{mg} / \mathrm{ml})$. Homogenates were prepared using a glass Potter-Elvejem homogenizer and centrifuged twice at $100.000 \mathrm{xg}$ for $30 \mathrm{~min}$. The final supernatant was considered to be the cytosolic fraction and once the protein concentration had been determined by the method of Lowry et al. (1951), it was adjusted to $2 \mathrm{mg} / \mathrm{ml}$. Aliquots were used immediatly or frozen and stored at $-80^{\circ} \mathrm{C}$.

\section{ENZYMATIC ACTIVITY}

Spectrophotometric determinations

Cholinesterase (ChE) activity was determined spectrophotometrically by a modified version of the Ellman procedure (Ellman et al., 1961; Rathaur et al., 1987) with acetylthiocholine iodide (ATCI) as a substrate. Next, $260 \mu$ of $0.1 \mathrm{M}$ PBS buffer ( $\mathrm{pH} 8$ ), $10 \mu \mathrm{l}$ of $10 \mathrm{mM}$ 5,5'-dithio-bis-(2-nitrobenzoic acid) (DTNB) solution (39.6 mg 5,5'-dithio-bis-(2-nitrobenzoic acid)) (DTNB), $15 \mathrm{mg}$ of sodium bicarbonate and $10 \mu \mathrm{l}$ of $0.1 \mathrm{M}$ PBS ( $\mathrm{pH} 7.2$ ), $2.5 \mu \mathrm{l}$ of $75 \mathrm{mM}$ substrate and $25 \mu \mathrm{l}$ of the sample was added to a microplate and the OD at 
$405 \mathrm{~nm}$ measured every minute. The increases in OD were converted to units per litre (Ellman et al., 1961). One unit was equivalent to a $1 \mu \mathrm{mol}$ of substrate hydrolyzed per minute per $\mathrm{mg}$ of protein. Inhibition assays were performed in microplates using the same method described above, except that samples ( $20 \mu \mathrm{l}$ of cytosolic fraction plus $5 \mu \mathrm{l}$ of each inhibitor) were first incubated at $37^{\circ} \mathrm{C}$ for $10 \mathrm{~min}$ before measuring the increase in OD. The final concentrations and inhibitors used were $400 \times 10^{3} \mathrm{nM}, 2 \times 10^{3} \mathrm{nM}, 2 \times 10^{2} \mathrm{nM}$ and $4 \mathrm{nM}$ of 1,5-bis(4-allyl(dimethylammoniumphenyl)pentan-3one dibromide) (BW284C51), and $50 \mathrm{mM}, 5 \mathrm{mM}, 0.5 \mathrm{mM}$ and $0.05 \mathrm{mM}$ of tetraisopropylpyrophosphoramide (isoOMPA). One unit was the equivalent of $1 \mu \mathrm{mol}$ of substrate hydrolyzed per minute per mg of protein, and the inhibition was calculated as the percentage of ChE activity in the controls.

\section{Electrophoretic assays}

Electrophoresis was performed according to the method of Laemli (1970) using a $6 \%$ polyacrylamide gel without SDS (100-200 $\mu$ g protein diluted 3:1 in glycerol per lane). The gels were incubated in $20 \mathrm{mg}$ of ATCI dissolved in $26 \mathrm{ml}$ of $0.1 \mathrm{M}$ PBS buffer ( $\mathrm{pH}$ 6) for $2 \mathrm{~h}$, to which the following were added sequentially: $2 \mathrm{ml}$ of $0.1 \mathrm{M}$ sodium citrate, $4 \mathrm{ml} 30 \mathrm{mM}$ $\mathrm{CuSO}_{4} .5 \mathrm{H}_{2} \mathrm{O}, 4 \mathrm{ml}$ distilled water and $4 \mathrm{ml} 5 \mathrm{mM}$ potassium ferricyanide. ChE activity produced brown bands in the gel after $2 \mathrm{~h}$. The bands were then fixed in $5 \%$ acetic acid.

\section{${ }^{3} \mathrm{H}-\mathrm{GABA}$ BINDING ASSAYS}

In the ${ }^{3} \mathrm{H}$-GABA binding assays performed, $1 \mathrm{ml}$ of $6.29 \mathrm{mg} / \mathrm{ml}$ of $D$. dendriticum adult extract was homogenized at $4^{\circ} \mathrm{C}$ for 10 minutes in two volumes of $20 \mathrm{mM}$ Tris-HCl buffer ( $\mathrm{pH}$ 7.4) as previously described by Pong \& Wang (1980). The homogenate was centrifuged at $1.000 \mathrm{~g}$ for five minutes, the pellet $\left(\mathrm{P}_{1}\right)$ was resuspended in fresh buffer (Tris-HCl buffer $\mathrm{pH} 7.4$ ) and the supernatant $\left(\mathrm{S}_{1}\right)$ was centrifuged at $60.000 \mathrm{~g}$ for 15 minutes. The final pellet $\left(\mathrm{P}_{2}\right)$ was resuspended in fresh buffer and was regarded as the membrane fraction. $\mathrm{P}_{2}$ fraction was incubated with increasing concentrations of ${ }^{3} \mathrm{H}-\mathrm{GABA}$ (specific activity $0.0441 \mathrm{Ci} / \mathrm{mmol}$ ): $1 \times 10^{-8} \mathrm{M}, 5 \times 10^{-8} \mathrm{M}$ and $10 \times 10^{-8} \mathrm{M}$ at $34^{\circ} \mathrm{C}$ for 30 minutes in the presence (non-specific binding) or absence (total binding) of a 1.000 fold molar excess of unlabeled GABA in Eppendorf tubes. In order to reduce the number of $\mathrm{dpm}$, and thus radioactivity, the ${ }^{3} \mathrm{H}-\mathrm{GABA}$ concentrations were prepared from a mixture of $9 \mu \mathrm{l}$ of $27 \mathrm{mM}{ }^{3} \mathrm{H}-\mathrm{GABA}, 4.5 \mu \mathrm{l}$ of unlabeled GABA and $455 \mu \mathrm{l}$ of $20 \mathrm{mM}$ Tris-HCl buffer ( $\mathrm{pH}$ 7.4). Each tube designated "non-specific binding" contained a final volume of $250 \mu \mathrm{l}$, in which $100 \mu \mathrm{l}$ of ${ }^{3} \mathrm{H}-\mathrm{GABA}$ was incubated with $100 \mu \mathrm{l}$ of $\mathrm{P}_{2}$ fraction, $10 \mu \mathrm{l}$ of
$100 \mathrm{mM}$ amino oxalacetic acid (AOAA) and $40 \mu \mathrm{l}$ of unlabeled GABA. Each tube designated "total binding", contained a final volume of $250 \mu \mathrm{l}$ comprising $100 \mu \mathrm{l}$ of the $\mathrm{P}_{2}$ fraction, $100 \mu \mathrm{l}$ of ${ }^{3} \mathrm{H}-\mathrm{GABA}, 10 \mu \mathrm{l}$ of $100 \mathrm{mM}$ amino oxalacetic acid (AOAA) and $40 \mu \mathrm{l}$ of $20 \mathrm{mM}$ Tris- $\mathrm{HCl}$ buffer ( $\mathrm{pH}$ 7.4). All assays were performed simultaneously with their respective controls. The incubation was terminated by rapid filtration through rinsed three times with $15 \mathrm{ml}$ ice-cold $20 \mathrm{mM}$ Tris- $\mathrm{HCl}(\mathrm{pH}$ 7.4). After incubation the filters were placed into plastic vials containing $2 \mathrm{ml}$ Aquasol II and the radioactivity was determined by liquid scintillation spectrometry using a Wallac 1410 liquid scintillation counter operating at $42 \%$ efficiency. The specific binding was calculated by substraction of the non-specific binding from the total binding.

\section{RESULTS AND DISCUSSION}

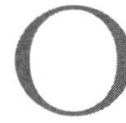
ur results demonstrated the presence of cholinesterases in the cytosolic fraction of $D$. dendriticum adult extract (Fig. 1). Since the gels employed in electrophoresis were not copolymerized with SDS and the sample buffer did not contain the detergent either because SDS inhibits enzymatic activity, it was impossible to determine the molecular weight of the enzyme. However, ChE activity was also quantified by the method of Ellman et al. (1961) and the rate was $2.11 \mathrm{U} / \mathrm{mg}$. In inhibition assays, the effect of specific inhibitors (BW284C51 and iso-OMPA) corroborated that to break down ATCI as substrate the parasite uses both acetylcholinesterases and pseudocholinesterases, as shown in Tables I and II.

Additionally, D. dendriticum adults are known to contain embryonated eggs, so the activity detected might be attributable to miracidia. In previous work, cholinesterase activity has also been found present in embryonated eggs (unpublished data). Activity by that

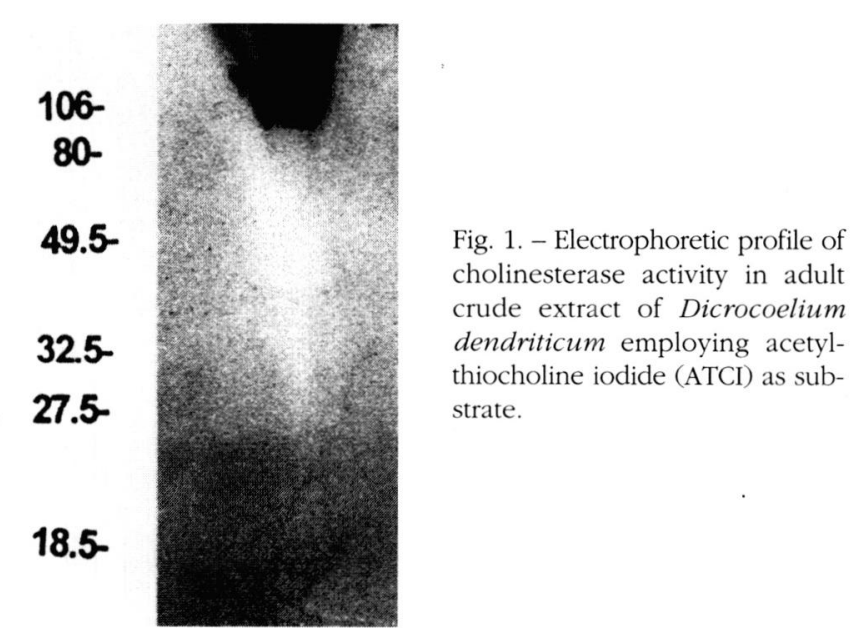




\begin{tabular}{ccc}
\hline & ChE activity (U/mg) (1) & \\
BW284C51 (nM) & $\mathbf{X} \pm$ SD & \% inhibition \\
\hline 0 & $2.11 \pm 0.37$ & 0 \\
400.000 & $1.71 \pm 0.35$ & $62.96^{*}$ \\
2.000 & $1.28 \pm 0.19$ & $72.22^{*}$ \\
200 & $1.71 \pm 0.40$ & $66.66^{*}$ \\
4 & $0.47 \pm 0.019$ & $90.74^{*}$ \\
\hline
\end{tabular}

${ }^{*} p \leq 0.05$.

Table I. - Cholinesterase activity in crude extract of adult Dicrocoelium dendriticum using acetylthiocholine iodide (ATCI) as substrate: inhibition by BW284C51. (1) The data value are the mean of three experiences \pm the standard deviation

\begin{tabular}{ccc}
\hline isoOMPA (mM) & $\begin{array}{c}\text { ChE activity (U/mg) (1) } \\
\mathbf{X} \pm \mathbf{~ S D}\end{array}$ & \% inhibition \\
\hline 0 & $2.11 \pm 0.37$ & 0 \\
50 & 0 & $100^{*}$ \\
5 & 0 & $100^{*}$ \\
0.5 & $0.85 \pm 0.025$ & $88.57^{*}$ \\
0.05 & $1.6 \pm 0.42$ & $80^{*}$ \\
\hline
\end{tabular}

${ }^{*} p \leq 0.05$.

Table II. - Cholinesterase activity in crude extract of adult Dicrocoelium dendriticum on acetylthiocholine iodide (ATCI) as substrate: inhibition by isoOMPA. (1) The data value are the mean of three experiences \pm the standard deviation.

same enzyme was recorded using the technique of Karnovsky et al. (1964), though only faint bands that could not be photographed appeared. Quantification according to the method of Ellman et al. (1961) revealed that the $\mathrm{ChE}$ rate was $0.44 \mathrm{U} / \mathrm{mg}$ protein. The GABA-receptor dissociation constant was $\mathrm{K}_{\mathrm{D}}=1.20 \mathrm{nM}$ and the receptor density $\mathrm{B}_{\max }=1.60 \mathrm{pmol} / \mathrm{mg}$ protein for the ${ }^{3} \mathrm{H}-\mathrm{GABA}$-specific binding site in $D$. dendriticum membranes as shown in Figures 2A,B. Affinity and receptor density were similar to the levels observed in the free-living nematode Caenorbabditis elegans $\left(\mathrm{K}_{\mathrm{D}}=\right.$ $37 \mathrm{nM} ; \mathrm{B}_{\max }=2.25 \mathrm{pmol} / \mathrm{mg}$ protein) (Schaeffer \& Bergstrom, 1988). However, affinity was lower than that observed in the parasitic nematode Trichinella spiralis $\left(\mathrm{K}_{\mathrm{D}}=1.20 \mu \mathrm{M}\right)$, though receptor density was very similar (4.78 $\mathrm{pmol} / \mathrm{mg}$ protein) (Ros-Moreno et al., 1999). In this study we have demonstrated the presence of ChE in the cytosolic fraction in both adults and embryonated eggs of the digenetic parasitic flatworm $D$. dendriticum. The enzymatic activity indirectly demonstrated the presence of acetylcholine. Additionally, this is the first discovery that GABA binding sites have been detected in the membranes of $D$. dendriticum adults. These are new data concerning the physiology of this parasite, whose habitat is the gallbladder and bile ducts of sheep. As other workers have postulated in other helmiths, it may be that GABA is
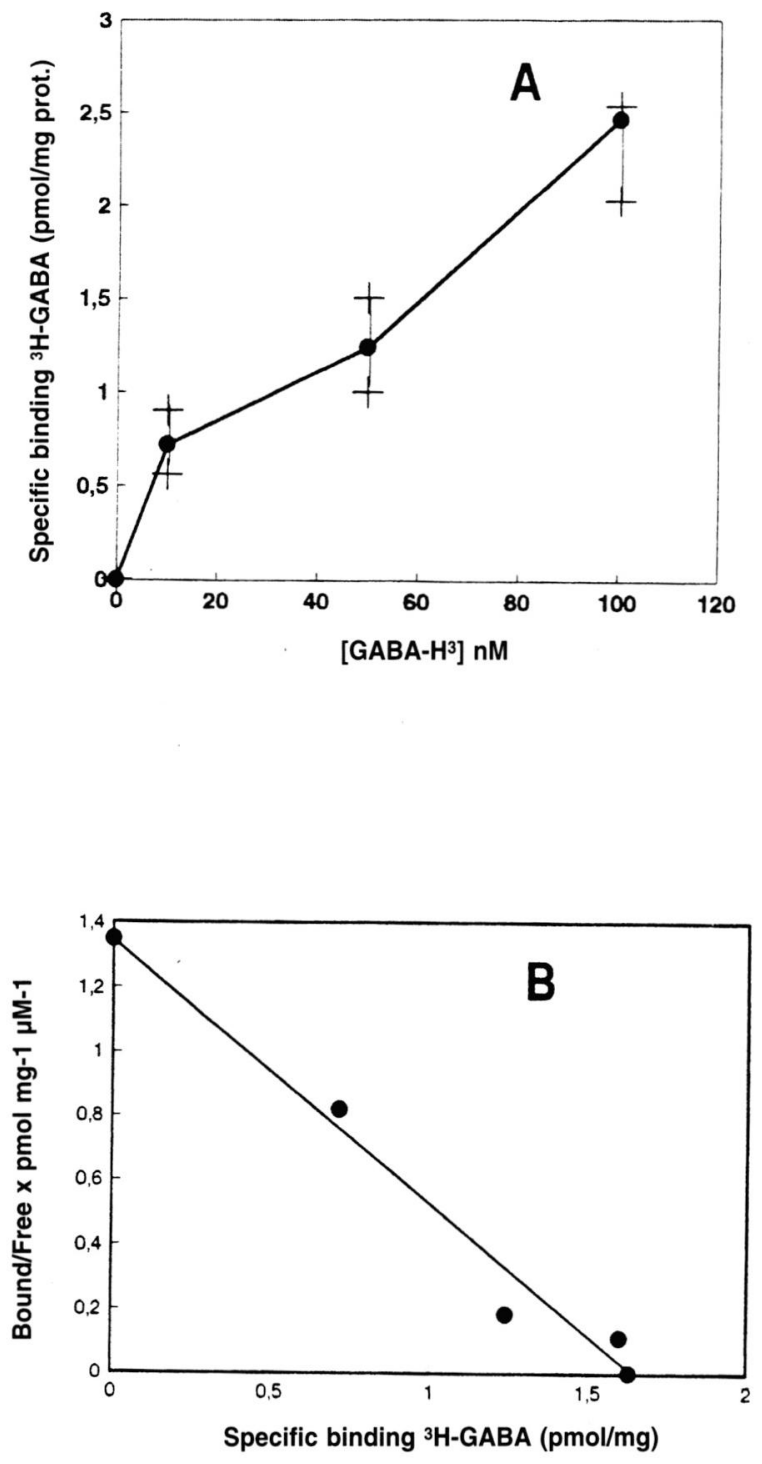

Fig. 2. $-{ }^{3} \mathrm{H}-\mathrm{GABA}$ specific binding in Dicrocoelium dendriticum membranes. A. Incubation of $D$. dendriticum with increasing concentrations of ${ }^{3} \mathrm{H}-\mathrm{GABA}$ (each data point being the mean of three determinations). B. Scatchard plot of the specific binding data shown in A.

a beneficial inhibitory neurotransmitter in the environment low in oxygen and could be the cornerstone of an inhibitory system depressing energy consumption more efficiently at low levels of oxygen (Nilson \& Wienberg, 1993; Eriksson et al., 1995). Further research may elucidate the existence of two separate neurotransmission systems depending on oxygen level, and this is our next point of action.

\section{ACKNOWLEDGEMENTS}

his research was supported by funds provided by Project PM96-0014 (Ministry of Education and Science, Spain), and Project 45/2000 (Alcalá 
University, Spain). Thanks are due to Rusell Sacks for his help with the English.

\section{REFERENCES}

Ellman G.L., Courtney K.D., Andres V. \& Featherstone R.M. A new and rapid colorimetric determination of acetylcholinesterase activity. Biochemical Pharmacology, 1961, 7, 88-95.

Eriksson K.S. \& Panula P. Gamma-aminobutyric acid in the nervous system of a planarian. The Journal of Comparative Neurology, 1994, 345, 528-536.

Eriksson K., Maule A.G., Halton D.W., Panula P.A.J. \& Shaw W C. GABA in the nervous system of parasitic flatworms. Parasitology, 1995, 110, 339-346.

Geary T.G., Klein R.D., Vanover L., Bowman J.W. \& ThompsON D.P. The nervous systems of helminths as target for drugs. Journal of Parasitology, 1992, 78 (2), 215-230.

KaRNOVSKY M.J. \& ROOTS L. A "direct-coloring" thiocholine method for cholinesterases. Journal of Histochemical Cytochemistry, 1964, 12, 219-221.

LAEMLI UK. Cleavage of structural proteins during the assembly of the head of the bacteriophage $\mathrm{T}_{4}$. Nature, 1970, 227, 680-685.

Lowry O., Rosebrough N., FarR A. \& Randall R. Protein measurement with the Folin phenol reagent. Journal of Biological Chemistry, 1951, 193, 265-275.

NiLSON G.E. \& WineBerg S. Changes in brain levels of GABA and related aminoacids in anoxic shore crab (Carcinus maenas). American Journal of Physiology, 1993, 264, R733-R737.

PONG S.S. \& W WANG C.C. Avermectin $B_{1 a}$ increases the number of GABA receptors in thoroughly washed rat brain membranes. Abstract Society Neuroscience $10^{\text {th }}$ Annu Meet Cincinatti, 1980, 6542, No 18422.

Rathaur S., Robertson B.D., Selkrik M.E. \& Maizels R.M. Secretory acetylcholinesterases from Brugia malayi adult and microfilarial parasites. Molecular and Biochemical Parasitology, 1987, 26, 257-265.

Ros-Moreno R.M., Moreno-GuZmán M.J., JimÉnez-González A. \& Rodríguez-CAABeIRo F. Interaction of ivermectin with gamma-aminobutiryc acid receptors in Trichinella spiralis muscle larvae. Parasitology Research, 1999, 85, 320-323.

SCHAEFFER J.M. \& BergStrom A.R. Identification of gamma-aminobutyric acid and its binding sites in Caenorbabditis elegans. Life Sciences, 1988, 43, 1701-1706.

WALKER R.J. \& HOLDEN-DYe L. Evolutionary aspects of transmitter molecules, their receptors and channels. Parasito$\log y, 1991,102$, S7-S29.

Walker R.J., Brooks H.L. \& Holden-Dye L. Evolution overview of classical transmitter molecules and their receptors. Parasitology, 1996, 113, S3-S33.

Reçu le 21 février 2000 Accepté le 5 mai 2000 